\title{
UNIVERSITYOF
}

FORWARD

THINKING

WESTMINSTER用

WestminsterResearch

http://www.westminster.ac.uk/westminsterresearch

Foreign Policy and the Ideology of Post-ideology: The Case of

Matteo Renzi's Partito Democratico

Brighi, E.

This is an Accepted Manuscript of an article published by Taylor \& Francis in The International Spectator, 51 (1), pp. 13-27.

The final definitive version is available online:

https://dx.doi.org/10.1080/03932729.2016.1121688

(C) 2016 Taylor \& Francis

The WestminsterResearch online digital archive at the University of Westminster aims to make the research output of the University available to a wider audience. Copyright and Moral Rights remain with the authors and/or copyright owners.

Whilst further distribution of specific materials from within this archive is forbidden, you may freely distribute the URL of WestminsterResearch: ((http://westminsterresearch.wmin.ac.uk/).

In case of abuse or copyright appearing without permission e-mail repository@westminster.ac.uk 


\section{Foreign Policy and the Ideology of Post-Ideology: the case of Matteo Renzi's Partito Democratico *}

Elisabetta Brighi (e.brighi@westminster.ac.uk)

Lilia Giugni (lg433@cam.ac.uk)

\section{Introduction}

As an aptly-titled and oft-quoted journal article by Sonia Lucarelli and Roberto Menotti observed a few years ago, Italy is no constructivist land (Lucarelli and Menotti 2002). What they and other constructivists such as Stefano Guzzini meant, is that ideas - and the study thereof - do not enjoy a prominent place in Italian International Relations (IR) or in the study of Italian foreign policy. It is no mystery that the interpretative turn common to most European social sciences was looked at with much suspicion in most Italian IR academic circles, if not overtly frowned upon by its more 'serious', i.e., traditional, scholars (as opposed to English-language scholars of Italian foreign policy, e.g., Davidson 2011). The reasons for this state of affairs are both simple and complex.

Firstly, Italy has a well-established and still preponderant materialist (and therefore anti-ideational and anti-interpretative) attitude to matters of foreign policy and international politics (Brighi and Petito 2011, 2012). On the one hand, Italy is the notorious birthplace of Niccolo' Machiavelli and of many a political realist after him. On the other, another materialist tradition, Marxism, held sway on the Left both intellectually and politically for a good part of the XX century. As strange bedfellows, Italian political realism and Marxism were united in stigmatizing interpretative research and ideas either as wishful thinking or mere superstructure respectively, and preferred focusing on the harsh realities and materialities of politics.

To complicate things further, another - and rather more crude - notion about the irrelevance of ideas can often be found circulating in Italian foreign policy circles and intellectual debates. This

\footnotetext{
* An earlier version of the paper was presented at the Conference 'The Italian Left and Foreign Policy', 9 June 2013 , Cambridge (UK). The authors wish to thank the Conference participants for their questions and observations. For their constructive comments and pointed criticisms, we would also like to thank Fabio Petito, Roberto Toscano, the Journal's two anonymous referees and a diplomat who wishes to remain anonymous.
} 
notion is linked to the issue of choices, or rather the lack of choices that supposedly mires Italian foreign policy. As the conventional wisdom goes, Italy is not and will never be a superpower. There is not much that Italy can do in international affairs and so - the mantra goes - why bother having ideas about it? What difference do ideas actually make? There are often no choices and little scope for manoeuvre, hence all Italy really needs is the reality check provided by realism or geopolitics or real-geo-politik, as Marco Antonsich (1997) aptly termed it - as well as a good dose of strategic flexibility. This notion is elevated to the category of fact, indeed a constant, that only the naïve ignore at their peril. It is often buttressed by those academic arguments that maintain a continuity thesis according to which Italian foreign policy does not really change, irrespective of who is leading the country and what their ideas or ideology may be (Croci 2005, 2008; Ratti 2012). The performative contradiction of this 'pragmatic' and structural position becomes apparent, however, as soon as one considers that its fatalism too is ideational in kind - originating in a particular belief, if not an inferiority complex, well-engrained in the collective psyche of a 'late-comer' state such as Italy.

There is, however, another story to be told. In the unsung history of Italian foreign policy since Unification, we find rich and diverse trajectories of thinking about international relations and foreign affairs, about Italy's place in the world, and about the future of the European and international order. Ideas, in a nutshell, have always actually existed and mattered. In broad terms, one can analytically identify at least three distinct outlooks, or traditions of thought, on Italian foreign policy (Brighi 2007; 2013): the nationalist, democratic and liberal outlook - as well as empirically many combinations of the same. These foreign policy outlooks emerged through time and materialised in a variety of contexts. In particular, political parties represented important sites of construction, discussion and contestation of ideas. It was here that foreign policy programmes and policies were predominantly imagined, articulated or restructured, before entering the sphere of government.

The Italian Left has a notable and long tradition of thinking about foreign policy; foreign policy, on the other hand, has always been a salient, if not critical area of politics for the Italian Left. Similar to some left-wing parties abroad (Stephanson 1994), a particular and underlying concern of the Italian Left regarded the link between foreign policy and domestic politics, especially the ways in which foreign policy would condition domestic political choices. This goes well beyond the familiar tropes of Cold War Anti-Americanism. Drawing on Giuseppe Mazzini's legacy, in the 1920s Gaetano Salvemini articulated a rich vision for Italy's foreign policy firmly centred around the idea of democracy, urging his countrymen to bring foreign policy out of its elitist dimension to involve 
public opinion and be fully accountable to it (Salvemini 1964; Bracco 1998). Internationally, Salvemini advocated a Mazzinian line for Italy - reformist, progressive and set on the ultimate goal of the promotion of international peace. Thirty years later, the Socialist Pietro Nenni understood how tightly interwoven domestic politics and foreign policy had become when he warned that 'avremmo avuto la politica interna della nostra politica estera', i.e., that Italy would have had 'the domestic politics of its foreign policy' (Nenni quoted in Canavero 1990: 225). Writing in the 1950s, Nenni was wary of post-Cold War international agreements that threatened to entangle Italy and curb its prospect for domestic growth - social, economic and moral (Benzoni 1967). He understood that foreign policy is not just the unproblematic articulation of a nation's interests and goals, but rather that foreign policy shapes and limits what nations are and can become (Campbell 1998). Hence, the importance of avoiding short circuits between objectives placed at different levels. The underlying concern within the democratic foreign policy outlook that the Left came to embody in the $20^{\text {th }}$ century was thus with maintaining the good health of democracy at home, its institutions and principles, including in matters of foreign policy, and avoiding any international arrangements that would place social progress out of reach.

If we now look at the political party which today embodies the mainstream of the Italian Left, the Partito Democratico (PD), a few questions are worth posing. Firstly, what foreign policy ideas have emerged within the party now that the long and difficult transition initiated at the end of the Cold War seems to have reached a degree of completion? What continuities and discontinuities can one observe between this foreign policy outlook and the broader democratic tradition to which it belongs? What role has the leadership of Matteo Renzi played in the coalescing of a new consensus around foreign policy, and can this consensus be considered post-ideological, or post-political? Finally, does Renzi's approach to foreign policy represent the negation of the role of ideas or is it perhaps the triumph of a very powerful idea, if not of an ideology that claims to end all ideologies?

\section{Ideas and Foreign Policy: Beyond Policy Paradigms}

Before tackling these questions, however, it is useful to clarify why this paper focuses on ideas and what exactly is meant by that. As argued elsewhere (Brighi 2013), from a theoretical standpoint, explanations of foreign policy that focus exclusively on either international or domestic factors are doomed to fail since they tend to miss a crucial, albeit sui generis, level of analysis. This level of analysis acts as a point of contact between actors and their environment and is constituted by those ideational prisms through which domestic and international developments are filtered (Sprout and 
Sprout 1965; Hay 2002; and on Italian foreign policy, Coralluzzo 2000). Ideas therefore are the lens through which foreign policy actors interpret and act in the world.

While this refocusing of foreign policy analysis on the role of ideas has been a generally welcome development, more work is clearly needed on the critical question of how to operationalise ideas. What kind of ideas matter? And where can they be found? Scholarship has so far tended to adopt a solution initially put forward by Peter Hall (1993) in equating ideas with 'policy paradigms'. As Colin Hay among others put it, policy paradigms are those intersubjectively agreed-upon narratives that provide templates through which political action and in particular change can be interpreted (Hay 2005). In the foreign policy field, paradigms thus can be understood as those sets of visions, ideas and traditions used by a certain political community to think collectively about its foreign policy and the international environment. Although effective as a first-cut operationalisation, however, the conceptual category of 'policy paradigm' is not devoid of problems, nor of ambiguities. Firstly, the all-encompassing nature of the concept of policy paradigm betrays its rather generic treatment of ideas, which are often lumped together despite their different levels of generality or the different uses they have. Further, the vocabulary of paradigms is reminiscent of Kuhnian philosophy of science and its 'revolutions', whereby old paradigms are replaced with new ones in what is predominantly a cognitive, rational process. This ignores the stickiness of norms and values, as well as the communicative function of discourse and ideas.

It is thus useful to turn to the rather more detailed conceptualisation of ideas recently put forward by Vivien Schmidt under the umbrella term of 'discoursive institutionalism' (2008; 2010). According to Schmidt, there are at least three levels of ideas that matter when generating (and analysing) political action and change. Starting from the highest level of generality, one firstly finds a set of 'deep philosophical ideas' (2010: 3), 'organising ideas, values and principles of knowledge' (2008: 306) and 'background public sentiment' - including the country's political culture and the orientations of society as a whole - that inform political actions. Moving down the ladder of generality there are then programmes, defined as those principles and frames of reference that 'define the problems to be solved [...]; the issues to be considered; the goals to be achieved; the norms, methods and instruments to be applied' (2008: 306). Finally, one arrives at policy ideas, which refer to specific propositions that inform particular policies and forms of action. Normally represented through discourse, understood broadly as including 'frames, narratives, myths, collective memories, stories, scripts and more' (Schmidt 2010: 3), ideas can be both cognitive (or strategic) and normative at every level. Taken in its entirety, Schmidt's conceptual palimpsest has the merit of distinguishing between background ideas that are subject to a slower pace of change 
and foreground ideas that impact policies more directly and contingently. Schmidt's conceptualisation also highlights the different functions and ways in which ideas affect political outcomes, in particular distinguishing between those ideas that are used to exchange and construct positions (taking place in the 'coordinative sphere') and those ideas that are used to seek public legitimation and deliberation (taking place in the 'communicative sphere').

If this is the understanding of ideas adopted in the paper, however, the question of whose ideas matter remains yet to be answered. After all, Schmidt's conceptualisation was originally laid out to explain institutional change and had especially governments in mind. In this paper, however, we deviate from Schmidt's original focus and wish to investigate the ideational and discursive processes of a different type of agent, the political party - and in particular the PD. In doing so, we build on and contribute to three strands of emerging scholarship: firstly, we expand on the work of those scholars who have recently applied discursive institutionalism to the analysis of change within political parties (Finlayson 2012); secondly, we follow the lead of those scholars who have investigated the contribution made by political parties to the framing and transmission of policy ideas (Hall 1993, Berman 1998); finally, we contribute to the growing literature exploring the role of political parties in foreign policy and the role of foreign policy in partisan discourse (Hill 2002; Rathbun 2004; Kaarbo 2012; Verbeek and Zaslove 2015).

Considering political parties as agents arguably requires an adjustment to Schmidt's original framework, however. The tripartite typology that discursive institutionalism utilizes to distinguish ideas according to their level of generality is arguably silent about a category of ideas that is however particularly central to partisan politics and identity, namely the category of political ideology. This is understood as a conceptual assemblage of values, meanings and beliefs that operate as benchmark vis-à-vis the political system, provide markers for the community of sympathisers, define the party's goals and help the party elites to select campaign issues and policy inputs (Giugni and Rubinelli 2015). It is at this intermediate ideological level that the 'battle of ideas', including ideas of foreign policy, can be particularly vivacious. Political ideology is affected by background public philosophies but also influences the way partisan actors frame policy programmes and make individual policy choices; in turn, it is also shaped by feedback generated by specific policy propositions. As such, ideology lies at an intermediate, porous level which however does not in itself guarantee an effective or straightforward mediation of the other levels - ideational levels are not always aligned and ideological goals can be ambiguous, divisive or not particularly explicit. 
In applying a qualified discursive institutionalist approach to the issue of foreign policy the paper not only draws attention to the issue of consistency across levels of ideas, but it also harks back to the old question of foreign policy goals, their formulation and the ever present danger of cacophony and inconsistency amongst these (Wolfers 1962: 67-80; Hill 2003: 97-126). While it is foolish and politically wrong to expect foreign policy actors to always know what their interests and goals are, and while a few actors can successfully navigate a degree of contradiction between goals placed at different levels, it is unsurprising to note that foreign policy failure strikes most where inconsistency of goals is practiced. Inconsistency of ideas placed at different analytical levels therefore creates the condition not only for weak and ineffective foreign policy actions, but for tensions and negative feedback that are potentially threatening to the life of the political agent in question - be it the survival of a government in power, or a political party vying for electoral success (Brighi and Hill 2012).

Therefore, in the rest of the paper we wish to examine how ideational changes occurred within the $\mathrm{PD}$ at the four levels outlined above have translated into patterns of alignment and misalignment, and what repercussions this had for foreign policy. Our argument is that while the post-communist Left experienced a long phase of strong misalignment, confusion and contradictions between ideas placed at different levels of analysis - leading also to frequent foreign policy crises when in government -, under the leadership of Matteo Renzi the PD is experiencing a moment of remarkable consistency across levels. While it may guarantee a certain degree of solidity to foreign policy itself, this alignment is problematic insofar as it has come about through Renzi's skilful creation of a new, post-ideological consensus able to selectively integrate disparate and mutually opposing ideational elements into a single package. By presenting these ideas as 'post-ideological' and, in an important sense, by explicitly wanting to move beyond ideologies, however, Renzi is making an ultimately ideological move whose limitations are starting to show below the surface of his and the party's recent and remarkable success.

\section{The Left in transition}

Much has been written on the process that brought the Italian Communist Party (PCI) - the largest communist organization in the Western world - to abandon its name and symbol and give rise, in 1991, to the Democratic Party of the Left (Partito Democratico della Sinistra, PDS) (Ignazi 1992; Baccetti 1997; Fouskas 1998). The dismissal of the old PCI took place during a period of profound systemic change, where the once solid 'Republic of the parties', as defined by historian Pietro 
Scoppola, was challenged on two fronts: from within, by new political actors and a vocal civil society frustrated by corruption scandals; and from without, by the obligations stemming from the Maastricht Treaty and the necessity to rethink Italy's position in the post-Cold War international system (Scoppola 1997; Pasquino 2009). As elsewhere in Europe, trends of mediatization and personalization were rocking the core of Italy's political values and attitudes to their foundations, weakening the legitimacy of the institutions of representative democracy and long-standing political doctrines (Poguntke and Webb 2005). To use Schmidt's words, the country was undergoing a substantial shift at the first ideational level, that of its 'background public philosophy' (Schmidt 2008). Against this changing landscape, the former communists attempted to redefine their ideology and bring their party to office. Weakened by an increasing factionalization, however, they directed most of their efforts towards the 'pars destruens' of the identity-rebuilding process rather than its 'pars construens' (Gritti and Prospero 2000). Forced to constantly emphasize the deepness of their renovation while simultaneously reassuring their most conservative constituencies, they refused to rename themselves as 'socialists' or 'social-democrats' and preferred the vaguer labels of 'left' and 'democracy' (Lazar and Giugni 2014). Preoccupied, if not obsessed, with this internal turmoil, the party elite struggled to fully grasp the new tendencies in the country's public sentiment and make sense of them in its public discourse. Furthermore, building on a traditionally Gramscian attitude towards Italian civil society, the party refused to adapt to cultural changes that it had the ambition to shape and guide (Gilbert 2008; Orsina 2013). At the same time, the ambiguities of the partisan ideology offered little guidance for the selection of policy inputs and their organization in coherent programmes, including in matters of foreign policy.

When the former communists merged with a group of progressive Christian Democrats in 2007, not much was gained in terms of ideational coherence, despite a number of novelties at various levels. The new-born Democratic Party (PD) presented itself as a stable majority party, appealing to both left-wing traditional constituencies and the moderate middle-class (Salvati 2003; Diamanti 2010). It selected its secretary through relatively open primary elections, it started to strongly personalize its leadership and make large use of political marketing techniques, marking its distance from traditional political parties. Crucially, the heirs of Italian Communism gradually started to abandon their ambition to build a cultural hegemony over Italian society. At least to some degree, they felt the urgency to align with a changing public sentiment and the approach to politics pioneered by Silvio Berlusconi and his centre-right. However, the PD's founding fathers were too ideologically divided to agree on the scope of this renewal and ensure consistency between ideational levels. Catholics and champions of secularism; supporters of classic social democracy as well as economic liberals; defenders of XX century's party politics and enthusiasts of 'liquid' organisations had all 
found their place within the PD project. The party's first leader and most enthusiastic promoter, Walter Veltroni, flirted more than others with the 'end of ideology' argument and took to heart the necessity to adapt the Italian left's discourse to the shifting public opinions - in a move that would anticipate that of Matteo Renzi years later. Yet, he largely underestimated the destructive potential of the PD's factionalization, under the mistaken assumption that contrasting positions could democratically and fruitfully coexist just as in the coalition party par excellence, the American Democrats. Under his successor Pierluigi Bersani, instead, a newly-established majority vowed to embrace the values of European socialism, abandon the catch-all strategy and re-evaluate the party as an ideational agent. This vision, however, remained highly contested within the party, which still hosted leftovers of little compatible ideologies and lacked, in many areas, a unitary approach towards policy-making (Giugni 2014).

In terms of the post-communist Left's approach to foreign policy, there is no doubt that the end of the Cold War had presented a momentous incentive to rethink Italy's place in the world, a process which however the former Communists engaged in only hesitantly, no doubt in part due to the rather peculiar way in which bipolarism had ended from their point of view (Giacomello and Verbeek 2011; Carbone 2011; Brighi 2013). In response to a growing foreign policy assertiveness professed by parties on the right, the PDS initially conjured up a foreign policy stance based on a continued (if by now atrophic) belief in the principles of multilateralism, humanitarianism and pacifism, tinged with varying degrees of anti-Americanism. This amounted to a norm-following behaviour that stressed the need to establish Italy as a reliable and credible 'good international citizen' - prioritizing those dimensions deemed to be less divisive, such as European integration (Aliboni 1996; Brighi 2007), fearing the growing prospect of marginalisation (e.g., in the UN Security Council; Fulci 1997) and lagging behind when confronted by the clear and imminent possibility of change. This majoritarian view of Italy's place in the world within the party, however, faced stiff competition from the extreme pacifist and vocally anti-American fringes (especially, Rifondazione Comunista, the Verdi and a small radical contingent within the PD itself). The salience and explosiveness of foreign policy issues was such that clashes of opinions often escalated into full-blown ideological confrontations, periodically threatening the unity of the party and the survival of the coalition when in government (Davidson 2011).

Mindful of this state of affairs, since its early days the PD tried to break with concessions to radical and anti-American fringes, as outlined in the party constitution and in the 2008 General Elections Manifesto. Veltroni's approach owed much to the Clintonian and Blairite Third Way paradigm and aimed at defusing intra-coalition tensions by a broad appeal to a liberal internationalist agenda. He 
thus described globalization as an undeniable reality and a source of inequalities, but also as an opportunity not to be missed; he professed continued support towards European political integration but was also conscious of the positive role of the transatlantic partnership; he embraced the liberal narrative of humanitarianism and peace promotion yet ensuring Italy's enduring commitment to a US-led world order (PD 2008). Such viewpoints, however, neither produced a clear foreign policy programme nor were shared by the entire party. In fact, foreign policy obtained little space in Veltroni's public speeches and in the 2008 electoral campaign, as public attention was mainly diverted on candidates' personalities and domestic matters (Lazar 2009). After periodic moments of difficulty experienced in response to Italy's participation in the US-led missions of Iraq and Afghanistan (Davidson 2011), and after especially the 'bipartisan' decision to withdraw from Iraq in 2005, foreign policy entered a phase of relative neutralisation. The manifestos of the 2009 party leadership candidates testify to the startling lack of definition of foreign policy ideas at this time.

After Veltroni's resignation in early 2009, his 'Third Way' vision was defended in the leadership primaries by his deputy Dario Franceschini. Franceschini stressed his awareness of the world's economic and political interdependence and considered a common EU foreign, security and social policy as the only feasible strategy for the 'government of globalization' (a key topic in the 2009 European Elections manifesto, that he substantially concurred to draft) (Franceschini 2009; PD 2009). His challenger, Pierluigi Bersani, gave voice to a more traditional left-wing support to world justice, workers' rights and international development, shared by the party's 'social-democratic' faction. He defended Europe not only as the most credible global player but above all as a home for a new progressive, reformist project. In both cases, general objectives and wishful thinking were by far preferred to specific goals and plans by both candidates. Foreign policy also gradually drifted off partisan discourse, remaining absent from the leadership contest campaign, including candidates' interviews and the pre-primaries televised debate on the party's web-channel, YouDem, to reemerge only when explicitly tied to domestic political considerations.

The transition of the Italian left from the Cold War to the post-Cold War environment was thus accompanied by a number of ideational changes that occurred at a different pace and at different levels of analysis. Far from resulting in a clear and coherent ideational renewal, the momentous background changes at the level of public ideology were only hesitantly responded to and in fact openly clashed, firstly, with the reluctance to abandon the Cold War paradigm and, secondly, with increasing factionalism at the level of the party's ideology and on a variety of foreign policy issues, especially those related to the use of force. Partisan ideology remained too contradictory to integrate effectively first level changes and the party's foreign policy programme as a result was 
underdeveloped, contradictory and vague. The misalignment between broad philosophies, ideology, programme and policy ideas put forward by the party during this time heavily conditioned not only its electoral success but the performance of centre-left governments when in power, as well as Italy's action on the world stage.

\section{Renzi’s PD}

At the 2012 coalition primaries, the media-friendly Florence mayor Matteo Renzi rose to challenge Bersani for leadership. The battle between the two soon became a battle for generational renewal that unlocked the PD's internal cleavages (not only post-communist versus former-Christian Democrats and 'Third Wayers' versus 'euro-socialist', but also young modernizers against party establishment). The PD's old guard closed ranks behind the incumbent and brought him to victory, but Renzi boosted his popularity and strengthened his legitimacy within the party and the middleclass electorate. When, at the 2013 General Elections, the alliance led by the PD failed to obtain an absolute majority and Bersani was forced to resign, he naturally appeared as the next in line. Having easily won the 2013 leadership contest, in few months Renzi replaced the fellow Democrat Enrico Letta as Prime Minister of a grand coalition government. During the following year, Renzi gradually managed to marginalise the internal opposition by gaining the support of the PD's youngest cadres and many of Bersani's former allies, while forcing the most proactive among his leftist opponents to abandon the party.

A large majority thus coalesced under the umbrella of a public ideology that seemed to combine pragmatism and broadly defined liberal-democratic values, on premises not different from those laid out by Veltroni in 2007. However, this time Renzi banned the word 'ideology' from his vocabulary, building the normative legitimacy of his own discourse precisely on the Manichean opposition between party politics with traditionally understood ideologies, on the one hand, and charismatic and pragmatic leadership, on the other hand. Renzi succeeded where Veltroni had failed, reducing the party's degree of fractionalization and making this narrative largely dominant within the PD. On the strength of his own considerable communicative skills, he achieved this by alchemically integrating in the partisan discourse many of the powerful tendencies that had entered the Italian public sphere and by progressively delegitimizing his internal rivals.

Renzi's understanding of the relations between party and civil society was, indeed, rather different from that of previous PD leaders. Born in the 1970s, Renzi had become politically involved after the end of the Cold War and Silvio Berlusconi's advent to power, and did little to hide his 
instrumental view of political parties, seen as an electoral machines rather than actors engaged in any ideational battle. Therefore, he willingly adapted the partisan discourse to changes occurred at the first ideational level, that of broad public orientations, playing by the rules of personalized and mediatized politics and openly flirting with both populist and technocratic arguments that discredited traditional party-based democracy (see Bickerton and Invernizzi Accetti 2013 and Giugni and Rubinelli 2015).

In matters of foreign policy too, Renzi managed to harmonize a rather jarring collage of values and interests while aligning his foreign policy programme to both a set of broad public orientations and his (post) ideological vision for the party (Di Donato 2013). Differently from some of his former Communist predecessors, who appeared overly concerned to blot out their left-wing credentials in order to gain credibility and respect abroad, Renzi had no burdensome past to account for and enjoyed ample scope of manoeuvre when it came to foreign affairs. Therefore, Renzi started by laying to rest the strong Cold War legacy of anti-Americanism and pacifism that had permeated so much of the Italian left, by blaming the failures of centre-left governments during the 1990s and 2000s explicitly on the excessively ideological stances of the radical party fringes.

In terms of Italy's place on the international scene, Renzi presented Italy's positioning within the three classic circles of the European Union, the Atlantic Alliance and the United Nations - with its implicity hierarchy - as natural and, to some degree, beyond discussion. Renzi had run for the party leadership playing the Euro-enthusiasm card, suggesting the enhancement of the European Parliament, the direct election of an EU President and the construction of a common European identity (Renzi 2013). On his appointment as Prime Minister he also wheedled voters with populist rhetoric and banked on being able to renegotiate the economic parameters within the EMU, pressuring Brussels to alleviate the austerity measures and pushing for more solidarity in Europe (Eurointelligence 2013; Tassinari 2014). Gradually, however, this stance was abandoned in the name of stability and continued cooperation with Germany and France (Riotta 2015). The recent Greek crisis was emblematic of Renzi's course, presented as pragmatic and yet fundamentally aligned with the decisions taken in Brussels, supporting the 'there is no alternative' narrative, while at the same time marginalising the claims of the more radical Left both at home and abroad (Huffington Post 2015). Two further examples perfectly epitomize Renzi's post-ideological attitude towards Europe. Firstly, in spring 2014 Renzi ignored the malaise of the party's Catholics and brought the PD in the Party of European Socialists - a move that both Veltroni and Bersani had attempted in vain and which gave Renzi an international platform and a stage from where to consolidate his governments' position. Secondly, the difficult negotiations for the appointment of 
Federica Mogherini as High Representative of the EU Common Foreign and Security Policy revealed other key elements of Renzi's approach - its extreme personalization, its ruthless (and declared) pragmatism, and its underlying narrative of presenting political and sometimes controversial choices as examples of an almost scientific problem-solving logic. Italy's rather lacklustre performance during the EU Presidency semester also mirrored this approach (Damilano 2015).

In terms of the Atlantic Alliance and Italy's bilateral relations with the US, Renzi has never hidden his Atlanticism and in fact openly professed it during leadership contests to distance himself once again from the rather more critical Bersani and de-legitimise his constituency (Unità 2012). Despite this, however, Italy has deviated from the path charted by the US on a number of occasions during Renzi's government, most importantly over the Ukrainian crisis. With the US pushing for sanctions against Moscow, Renzi rather followed in the footsteps of former Prime Ministers Romano Prodi and Silvio Berlusconi in cultivating a special relationship with Russia and opposing any intransigent stance, when not offering his services as a mediator (Euobserver 2015). Renzi's pro-Russian attitude has revealed itself less as a principled stance than the triumph rather of a purely economic rationale driven by Italy's traditional energy dependence (Labbate 2010). Italy's foreign policy in the area seems to be strongly influenced by ENI's priorities (Bini 2013, 2015) - with Renzi on one occasion involuntarily admitting the company's centrality to not only the country's diplomatic projection but also its intelligence efforts in the area (Il Fatto Quotidiano 2014). The degree of openness if not vulnerability of Italy's foreign policy to strong economic interests, not just over Russia but also in sectors such as the growing European defence industry, derives from major Italian corporate interests, from ENI to Finmeccanica, and arguably benefits these stake-holders first and foremost. Although none of this is particularly new - since the end of the Cold War a special relation with Russia was cultivated by both centre-left and centre-right governments (Brighi 2011) - the way in which Renzi welcomed this state of affairs is indeed new. Rather than defensively accommodating the priorities and needs of corporate actors, Renzi welcomed them under his 'big tent' and rather mercantilist approach, signalling a full and committed embracing of the forces driving economic globalisation.

Concerning the last circle of Italy's participation in the UN and more generally in the global theatres of international politics, Renzi managed to restructure the party line on a number of dossiers, especially concerning the Middle East. In an unprecedented move among leaders of the centre-left, and mirroring rather than countering a diminishing European support post-9/11, Renzi distanced himself from the party's traditional pro-Palestinian stance and appeared lukewarm over 
the opportunity of recognising Palestine as a State (Di Donato 2013; Samra 2014). The recent vote in Parliament captured his government's reluctance graphically, with Italy 'deciding not to decide' on the matter, thus distancing itself from the recognition made, among others, by Great Britain and the Vatican. Renzi's conservative approach to the regional balance of power in the Middle East has also translated into a relative hostility towards Iran, again in clear rupture with the positions of dialogue of previous party leaders and, even more problematically, in a recent rapprochement with the Egypt of al-Sisi. In praising Egypt's role as guarantor of the region's stability, Renzi turned a blind eye not only to al-Sisi's anti-democratic tendencies, essentially dismissing the participatory claims made by the Arab Spring movement and mirroring a broader conservative turn within the transatlantic community (Borri 2015), but he also dismissed some of the Italian left's most longstanding values, such as the normative commitment to legitimacy and the protection of human rights and the rejection of raison d'État in matters of foreign policy.

Renzi's foreign policy programme and ideas have thus changed the landscape of the centre-left and replaced the party's fuzzy approach of the past with the stark traits of a new consensus. Rather than founded on entirely new premises, Renzi has created his own blend of foreign policy by folding old and new elements into the same mix - mercantilism with Atlanticism, multilateralism and conservatism, 'big tent' capitalism with realism - a set of values in apparent yet functional opposition. All of this is arrived at through a considerable degree of centralisation, including in the process of selection and articulation of goals, and presented as a pragmatic if not technical solution to problems, rather than an ideological stance. For the first time in the troubled history of the postCommunist Left, thus, one could argue that this has led to a relative alignment of the three levels of public orientations, partisan ideology and policy programmes around an emerging consensus that shows all the defining traits of post-ideology.

\section{Conclusions}

In his determination to end the grip that ideological battles had on the party, cut the umbilical cord that united it to its Cold War history and secure an uncontested leadership, Renzi has projected Italy into the realm of post-ideology. By perfecting and completing the gradual and difficult process of Italy's cultural, economic and political integration into globalisation, however, Renzi has recast the PD's and the country's foreign policy as little more than the management of neo-liberal interdependence. There is no doubt that his approach to both his party and foreign policy reflect the main tenets of post-ideological politics as described by Pierre Bordieu and Chantal Mouffe among 
others: the strategic framing of ideologies as 'old' ways of understanding politics vs. the 'new' ways of pragmatic problem-solving; a penchant for technical rather than principled solutions and for extreme personalization bordering on populism; the acceptance of the late logic of capitalism and neo-liberal interdependence as non-negotiable facts (Bordieu 1998; Mouffe 2005).

In terms of Schmidt's conceptualisation, these principles have trickled from the level of background public philosophy (common to many European countries) down and across the other ideational levels - party's political ideology, foreign policy programme and policy. Our argument is that this new-found alignment can guarantee a certain stability and success, including in foreign policy, but comes at a heavy price: firstly, an increasing centralization and an impoverished debate; secondly, the renunciation of a genuinely progressive understanding of both the party and of the country's foreign policy in favour of an essentially conservative and status-quo orientation; thirdly, the possibility that foreign policy might backfire and, through a process of negative feedback, challenge Renzi's carefully constructed new post-ideological consensus to show its opaque and ambiguous nature. The development charted by the paper sets Renzi rather apart from the Salveminian legacy of subordinating foreign policy commitments to the necessity of domestic progressive reforms. It is evident that Renzi's 'post-ideological' framework represents in itself a powerful ideology, perhaps less structured than most of the XX century's political doctrines, but certainly one gaining and reflecting an increasingly wider societal consensus not just within Italy but across Europe. Our analysis suggests not only that the 'end of ideology' thesis should be dismissed, and that the role of ideas and ideologies is still worth analysing, but that further investigation is needed into the ways in which the particular ideology of 'post-ideology' is affecting partisan discourse and foreign policy in other European countries. 


\section{Bibliography}

Aliboni, R. and Greco, E. (1996) 'Foreign Policy Re- nationalization and Internationalism in the Italian Debate', International Affairs 72(1): 43-51.

Anderson, P. (2009) 'An Invertebrate Left', London Review of Books, 12 March.

Antonsich, M. (1997), 'La geopolitica italiana nelle rivista 'Geopolitica', 'Hérodote/Italia (Eurodoto)' e 'Limes’, Bollettino della Società Geografica Italiana, 3, pp. 411-418.

Armellini, A. (2015) 'Renzi seeks to end Putin's international isolation', Euobserver, 6 March, available at https://euobserver.com/foreign/127896

Baccetti, C. (1997) Il Pds, Bologna: Il Mulino.

Benzoni, A. Gritti, R. and Landolfi, A. (1993) La dimensione internazionale del socialismo italiano: 100 anni di politica estera del PSI, Roma: Edizioni Associate

Berman, S., (1998) The Social Democratic Moment: Ideas and Politics in the Making of Interwar Europe, Cambridge, MA: Harvard University Press.

Bickerton, C., Invernizzi Accetti, C. (2013), 'Matteo Renzi. The limits of doing', in Le Monde Diplomatique, available at http://mondediplo.com/blogs/matteo-renzi-the-limits-of-doing

Bini, E. (2013) La potente benzina italiana. Guerra fredda e consumi di massa tra Italia, Stati Uniti e Terzo mondo (1945-1973) (Roma: Carocci).

Bini, E. (2015) 'A Model of Growth in Crisis: Italy's Energy Policies at the end of the Cold War', paper presented at the workshop 'Italy: From Crisis to Crisis', Cornell University, 11 June.

Borri, F. (2015) 'Matteo Renzi sbaglia ad appoggiare Al Sisi', Internazionale, 12 Luglio, available at http://www.internazionale.it/opinione/francesca-borri/2015/07/12/matteo-renzi-al-sisi

Bourdieu, P. (1998) “The Essence of Neoliberalism," Le Monde Diplomatique, December 1998, mondediplo.com/1998/12/08bourdieu.

Bracco, B (1998). Storici italiani e politica estera: tra Salvemini e Volpe 1917-1925, Milano: Franco Angeli. 
Brighi, E (2007) 'Europe, the US and the 'Policy of the Pendulum': The Importance of Policy Paradigms in the Foreign Policy of Italy (1989-2005)', Journal of Southern Europe and the Balkans 9, no. 2: 99-115.

Brighi, E. (2011) 'Resisting Europe? The case of Italy's foreign policy', in The Europeanization of National Foreign Policies, edited by C. Hill and R. Wong (London: Routledge).

Brighi, E. (2013) Foreign Policy, Domestic Politics, International Relations: The Case of Italy (London: Routledge).

Brighi, E and Hill, C. (2012) 'Implementation and Behaviour', in Foreign Policy Analysis in International Relations, eds. S. Smith, T. Dunne, and A. Hadfield (Oxford: OUP, 2nd ed.).

Brighi, E. and Petito, F. (2011) 'The Renaissance of Geopolitics in post-1989 Italy', Geopolitics 17 (1), 819-45.

Brighi, E. and Petito, F. (2012) 'Geopolitics in the "Land of the Prince": A Passe-Partout to Global Power Politics?', in The Return of Geopolitics in Europe? ed. Stefano Guzzini (Cambridge, CUP)

Campbell, D. (1998) Writing Security: United States Foreign Policy and the Politics of Identity, Minnesota: Minnesota University Press.

Canavero, A. (1990) 'Nenni, i socialisti e la politica estera', in Di Nolfo, E. Rainero, R. H. and Vigezzi, B. (eds) L'Italia e la politica di potenza in Europa, 1945-1950, Milano: Marzorati

Carbone, M. (ed.) (2011) Italy in the Post-Cold War: Adaptation, Bipartisanship and Visibiity, Lanham: Lexington Books.

Carlsnaes, W. (2002) 'Foreign Policy', in Carlsnaes, W., Simmons, B. and Risse-Kappen, T. (eds) Handbook of International Relations, London: Sage.

Civati, G. (2013) Dalla delusione alla speranza, available htto www.unità.it

Coralluzzo, V. (2000) La politica estera dell'Italia repubblicana, 1946-1992: modello di analisi e studio di casi, Milano: FrancoAngeli.

Croci, O. (2005) 'Much Ado about Little: The Foreign Policy of the Second Berlusconi Government', Modern Italy 10(1): 59-74.

Croci, O. (2008) 'The Second Prodi Government and Italian Foreign Policy: New and Improved or the Same and Wrapped up Differently?', Modern Italy 13(3): 137-55. 
Cuperlo G. (2013) Per la piattaforma della dignità. Piattaforma congressuale di Gianni Cuperlo, available http: www.unità.it

Damilano, M. (2015) 'Semestre europeo, il flop di Matteo Renzi', L’Espresso, 12 January.

Davidson, J. W. (2011) America's Allies and War: Kosovo, Afghanistan, and Iraq, New York: Palgrave.

Di Donato, M. (2014) The rise of Matteo Renzi and Italy's international role, available at http://blogs.lse.ac.uk/ideas/2013/11/the-rise-of-matteo-renzi-and-italys-international-role/

Diamanti, I. (2009) Bianco, rosso, verde, azzurro e.. tricolore. Le mappe dell'Italia politica, Bologna: Il Mulino.

Diamanti, I. (2010) 'Vizi e virtù del partito impersonale' in La Repubblica, 8th November.

Eurointelligence (2013), 'Renzi says he will stand up to Merkel - really?', 28 October, available at http://www.eurointelligence.com/news-details/article/renzi-says-he-will-stand-up-to-merkelreally.html

Finlayson, A. (2013) 'From Blue to Green and Everything in Between: Ideational Change and Left Political Economy After New Labour', The British Journal of Politics and International Relations $15,70-88$.

Fouskas, V. (1998) Italy, Europe, the left, Aldershot: Ashgate.

Franceschini, D. (2009) Fiducia, uguaglianza, merito, qualità, available http://www.partitodemocratico.it

Giacomello, G. and Verbeek, B. (eds) (2011) Italy's Foreign Policy in the Twenty-First Century, (Lanham: Lexington Books).

Gilbert, M. (2008) 'In search of normality: the political strategy of Massimo D'Alema' in Journal of Modern Italian studies, 3:3, 307-317.

Giugni, L and Rubinelli, L. (2015), 'The Italian PD: ideas, discourse and party change', paper presented at the Council of European Studies Annual Conference, Paris, July 2015.

Giugni, L. (2014) 'The Italian Left at a crossroads', in Renewal, London: Lawrence \& Wishart. 
Hall P. A. (1993), Policy Paradigms, Social Learning, and the State: The Case of Economic Policymaking in Britain, Comparative Politics, 25, 3, 275-296.

Hay, C. (2002) Political Analysis: A Critical Introduction, Basingstoke: Palgrave.

Hill, C. (2002) Cabinet Decisions on Foreign Policy: The British Experience, October 1938-June 1941 (Cambridge: Cambridge University Press).

Hill, C. (2003) The Changing Politics of Foreign Policy, Basingstoke: Palgrave Macmillan.

Huffington Post (2015), 'Grecia, Matteo Renzi stronca Alexis Tsipras: "Non pensi di essere più furbo degli altri"”, 30 June.

Ignazi, P. (1992) Dal Pci al Pds, Bologna: Il Mulino.

Il Fatto Quotidiano (2014), 'Renzi, gaffe in tv su Eni: “E' un pezzo fondamentale dei nostri servizi segreti", 4 April, available at http://www.ilfattoquotidiano.it/2014/04/04/eni-renzi-a-otto-e-mezzopezzo-fondamentale-della-nostra-intelligence-brunetta-gaffe-inqualificabile/939651/

ISPI (2015) Rapporto 2015. In mezzo al guado. Scenari globali e l'Italia (Novi Ligure: Edizioni Epoké).

Istituto Affari Internazionali (1993) 'The Dual Crisis', The International Spectator 28: 1, 5-30.

Kaarbo, J. (2012) Coalition Politics and Cabinet Decision Making: A Comparative Analysis of Foreign Policy Choices (Ann Arbor: University of Michigan Press).

Labbate, S. (2010) Il governo dell'energia. L'Italia dal petrolio al nucleare (1945-1975) (Florence: Le Monnier).

Lamborn, A. C. (1991) The Price of Power: Risk and Foreign Policy in Britain, France and Germany, Boston: Unwin Hyman.

Lazar, M. (2009) L’Italia sul filo del rasoio, Milan: Rizzoli.

Lazar, M. and Giugni, L. (2014), 'From Communism to Centre Left. Analysis of an unprecedented political trajectory', in Mammone, A., Veltri, G. and Parini, G. (eds.) Routledge Handbook of Contemporary Italy, London: Routledge.

Lucarelli, S. and Menotti, R. (2002) 'No Constructivists' Land: International Relations in Italy in the 1990s' Journal of International Relations and Development 5(2): 114-42. 
Mouffe, C. (2005) On the political (Abingdon: Routledge).

Orsina, G. (2013) Il berlusconismo nella storia d'Italia (Rome: Marsilio).

Panebianco, A. (1977) 'La politica estera italiana: un modello interpretativo', il Mulino 254: 84579.

Panebianco, A. (1982) Modelli di partito. Organizzazione e potere nei partiti politici (Bologna: Il Mulino).

Partito Democratico (2008) Il programma di governo del PD, available http://www.partitodemocratico.it

Partito Democratico (2009) L'Europa che conviene. Le idee e i programmi del PD per le elezioni europee, available http://www.partitodemocratico.it

Pasquino, G. (ed.) (2009) 'Political History in Italy’ in Journal of Policy History, 21: 282-297.

Poguntke, T. and Webb, P. (2005) The Presidentialization of Politics: A Comparative Study of Modern Democracies, Oxford: Oxford University Press.

Prospero, M. and Gritti, R. (2000) Modernità senza tradizione, Lecce: Piero Manni editore.

Rathbun, B. C. (2004) Partisan Interventions: European Party Politics and Peace Enforcement in the Balkans (Ithaca: Cornell University Press).

Ratti, L. (2012) 'All aboard the bandwagon? Structural Realism and Italy's international role', Diplomacy \& Statecraft 23(1): 87-109.

Renzi, M. (2013) Cambiare Verso, Documento Congressuale a Sostegno della Candidatura di Matteo Renzi, available http://www.matteorenzi.it

Romero F (2014) 'L'Italia nelle trasformazioni internazionali di fine Novecento', in Pons S, Romero F and Roccucci A (eds) L'Italia contemporanea dagli anni Ottanta a oggi, vol. I: Globalizzazione, Roma: Carocci.

Salvati, M. (2003) Il Partito Democratico, Bologna: Il Mulino.

Salvemini, G. (1964) Dalla guerra mondiale alla dittature (1916-1925), Milano: Feltrinelli. 
Samra, M. (2014) 'Italian-Palestinian Relations: What Went Wrong?', Jadaliyya, 30 August, available at http://www.jadaliyya.com/pages/index/19047/italian-palestinian-relations_what-wentwrong

Schmidt, V. (2008) 'Discursive Institutionalism: The Explanatory Power of Ideas and Discourse', in Annual Review of Political Science, 11: 303-326.

Schmidt, V. (2010) 'Taking ideas and discourse seriously: explaining change through discursive institutionalism as the fourth 'new institutionalism', European Political Science Review, 2:1, 1-25.

Scoppola, P. (2009) La democrazia dei cittadini, Rome: Ediesse.

Tassinari, F. (2014), 'Can Matteo Renzi Move Mainstream Europe?' Huffington Post, 20 September.

Unità (2012), 'Bersani-Renzi: le differenze politiche in 10 punti', 30 November, available at http://www.unita.it/italia/speciale-primarie-del-centrosinistra/bersani-renzi-le-differenze-brpolitiche-in-dieci-punti-1.470023 .

Verbeek, B. and Zaslove, A. (2015) 'The impact of populist radical right parties on foreign policy: the Northern League as a junior coalition partner in the Berlusconi Governments', European Political Science Review 7: 4 (2015): 525-546.

Wolfers, A. (1962) Discord and Collaboration: Essays on International Politics (Baltimore: The John Hopkins Press. 